\title{
Vaccination during the First Diagnosis of Multiple Myeloma: A Cohort Study of the French National Health Insurance Database
}

\author{
Guilhem Tournaire ${ }^{1}$, Cécile Conte ${ }^{1,2,3,4}$, Aurore Perrot ${ }^{5}\left(\mathbb{D}\right.$, Maryse Lapeyre-Mester ${ }^{1,2,3,4,6}(\mathbb{D})$ \\ and Fabien Despas 1,2,3,4,6,* \\ 1 Service de Pharmacologie Médicale et Clinique, CHU de Toulouse, 31000 Toulouse, France; \\ guilhem.tournaire@yahoo.com (G.T.); cecile.conte@univ-tlse3.fr (C.C.); \\ maryse.lapeyre-mestre@univ-tlse3.fr (M.L.-M.) \\ 2 UMR1027, Inserm, Université Paul Sabatier, 31330 Toulouse, France \\ 3 Service de Pharmacologie Médicale et Clinique, Faculté de Médecine, Université Paul Sabatier, \\ 31000 Toulouse, France \\ 4 Centre Midi-Pyrénées de Pharmacovigilance, de Pharmacoépidémiologie et d'Informations \\ sur le Médicament, Centre Hospitalier Universitaire de Toulouse, 31000 Toulouse, France \\ 5 Département d'Hématologie et de médecine Interne, Institut Universitaire du Cancer-Oncopole, \\ CHU de Toulouse, 31000 Toulouse, France; perrot.aurore@iuct-oncopole.fr \\ 6 INSERM Centre d'Investigation Clinique 1436 Toulouse, Centre d'Investigation Clinique de Toulouse, \\ Centre Hospitalier Universitaire de Toulouse, 31000 Toulouse, France \\ * Correspondence: fabien.despas@univ-tlse3.fr; Tel.: +33-561-145-961; Fax: +33-561-145-642
}

Received: 21 October 2020; Accepted: 29 November 2020; Published: 2 December 2020

check for updates

\begin{abstract}
Purpose: Infections are frequent and often result in serious complications in patients with multiple myeloma (MM). Prophylactic vaccination is recommended for influenza virus, Streptococcus pneumoniae (SP), and Hemophilus influenzae b (Hib). The aims of this study were to measure the vaccination rates within 24 months after the diagnosis of multiple myeloma and to identify factors associated with vaccine use. Methods: MM patients were selected through the French national health insurance database from 1 January 2010 to 31 December 2015. Patients with a previous history of MM were excluded. Results: Vaccination rates against influenza, SP, and Hib among 22,831 newly diagnosed MM patients were, respectively, 28.5\%, 10.3\%, and $1.4 \%$. Only $0.7 \%$ received all three vaccines. Factors associated with vaccination were young age, male gender, an absence of comorbidity, a history of higher medication and vaccine consumption, Herpes simplex virus (HSV), Varicella zoster virus (VZV), and the use of pneumocystis prophylaxis. Conclusion: The low rates of vaccination indicate the need to improve physician and MM patient adherence and education regarding vaccination.
\end{abstract}

Keywords: pharmacoepidemiology; vaccines; French national health insurance database; multiple myeloma; infectious diseases

\section{Introduction}

New treatments introduced over the past decades have improved the survival of multiple myeloma (MM) patients [1-3]. Managing the complications of the disease and its treatments, including infections, is crucial as MM patients are living longer [4]. Infections remain a significant cause of morbidity and a leading cause of death in MM patients [5,6]. In a study of over $9000 \mathrm{MM}$ patients, Blimark and colleagues observed that $22 \%$ of the deaths within the first year after diagnosis were from infections [7]. MM patients were 7 times more at risk for bacterial infections and 10 times more for 
viral infections compared to matched controls [7]. MM immunodeficiency is both humoral, with B-cell dysfunction leading to polyclonal hypogammaglobulinemia, and cellular, with T-cell, dendritic-cell, and NK-cell abnormalities [8]. Immunodeficiency starts as early as when the plasma cell disorder begins. Studies have shown an increased risk of infection in patients with monoclonal gammopathy of undetermined significance (MGUS) $[9,10]$. Low immune response to infections and vaccines has also been shown in MM patients and has been predictive of a higher risk of infection [11,12].

As a result of this immunosuppression, MM patients are notably at risk for developing infections involving encapsulated pathogens, such as Streptococcus pneumoniae (SP) and Hemophilus influenzae b (Hib), as well as viral infections [13]. Despite the impaired response to vaccines [14], prophylactic vaccination has been recommended by the International Myeloma Working Group (IMWG) for influenza virus, SP, and Hib since 2002 [15]. These recommendations have since been re-emphasized in 2013 and $2017[13,16]$.

To our knowledge, no previous population-based study has been conducted to evaluate the rate of vaccination and hospitalization imputable to infections in MM patients. Consequently, we tried to address these questions on a nationwide level using exhaustive data from the French national health insurance database. Therefore, the aims of our study were to assess $S P, H i b$, and influenza vaccination rates in newly diagnosed adult MM patients and to identify factors associated with a recommended vaccination.

\section{Method}

\subsection{Data Sources}

A retrospective pharmacoepidemiological cohort study was conducted using data from the French national health insurance database (SNDS). This database provides information on the healthcare coverage for approximately $98.8 \%$ of the French population [17]. The SNIIRAM (Système national d'information inter-régimes de l'Assurance maladie; National health insurance interplan information system) database contains exhaustive, anonymous individual data on patient healthcare reimbursements. It includes patient characteristics such as age, gender, vital status, and long-term and chronic diseases. It also includes data on ambulatory care with all reimbursed drugs from community pharmacies and all reimbursed medical interventions (with the French medical intervention classification coding (CCAM)). Through the French hospital discharge database (PMSI) several years of inpatient care all over France can be followed exhaustively. The PMSI includes the following data: the number of hospitalizations, admission and discharge dates, length of stay, type of hospital, and medical data coded according to the International Classification of Diseases, 10th revision (ICD-10) with diagnosis codes (main, related, and associated) $[17,18]$.

\subsection{Selection of MM Incident Cases}

Patient selection is presented in the study flowchart (Figure 1). Data were extracted for patients presenting with a diagnosis of MM in the PMSI between 1 January 2010 and 31 December 2015. The ICD-10 code used was C90 "Multiple myeloma and malignant plasma cell neoplasms".

Incident MM cases were identified according to the validated algorithm defined by Palmaro et al. [19]. This algorithm has a sensitivity of $90 \%$, a specificity of $100 \%$, and a predictive positive value of $60 \%$ [19]. The diagnosis date was then defined as the first hospitalization date for MM found in our dataset, according to the algorithm. 


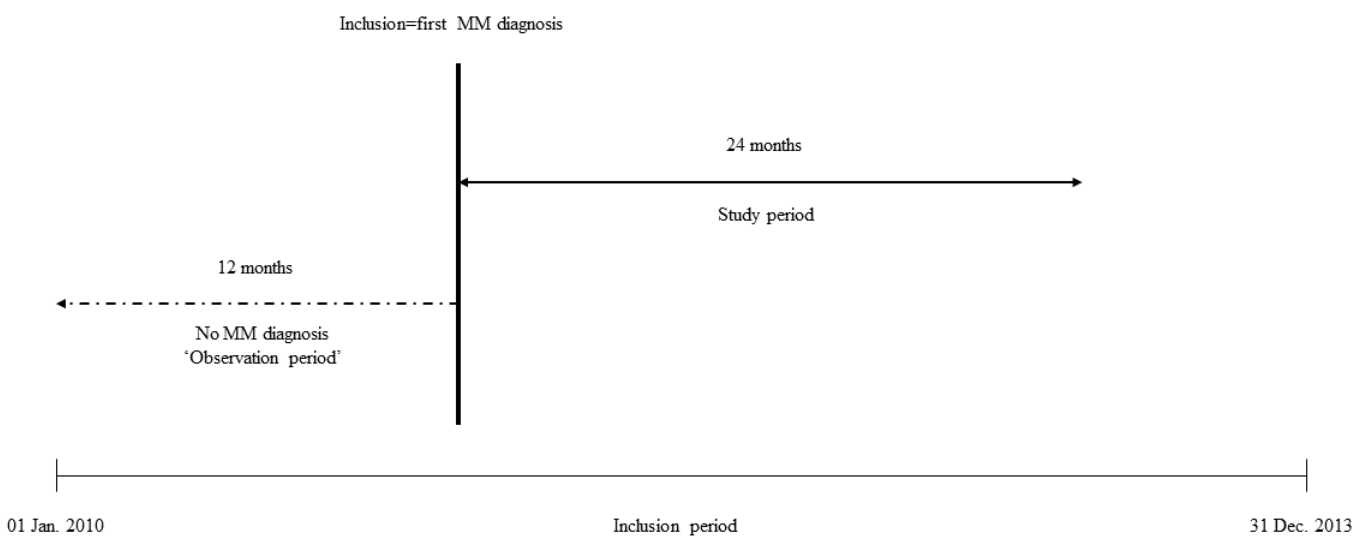

Figure 1. Study design-representation for a given patient.

\subsection{Observation and Study Periods}

To ensure identification of new MM cases, we defined an observation period as the 12 months prior to the first date of MM diagnosis, which meant that we included only patients with the first diagnosis as of 1 January 2011 (Figure 1).

The study period corresponds to the 24 months following the date of the diagnosis. Therefore, we included only patients with the first diagnosis up to 31 December 2013.

\subsection{Definition of Outcomes}

To meet the criteria for vaccination (primary outcome) patients had to have had at least one reimbursement for each of the three recommended vaccines during the study period. As influenza vaccine is recommended and free of charge for people 65 years of age and older in France [20], we searched for $S P$ or Hib vaccines only for our secondary outcome. In fact, this is more MM specific since most of our study population was older than 65 years of age. Vaccines of interest were identified by their Anatomical Therapeutic Chemical (ATC) code: influenza vaccines (J07BB), SP vaccines (J07AL), and $H i b$ vaccines (J07AG) [21].

Our analyses included incident MM cases with reimbursement of the three vaccines or at least an $S P$ or Hib vaccine (depending on the outcome) during the study period. Patients with vaccine reimbursement were compared to incident MM cases without reimbursement of the three vaccines or of an SP or Hib vaccine (depending on the outcome) during the study period.

\subsection{Covariates}

The data source that we used comes from medicoadministrative data. In addition, some precise clinical data cannot be available (i.e., patient weight, proteinuria, etc.), while data that are difficult to collect in clinical practices are possible such as the level of consumption of care generating reimbursement. In addition, among the available data, we have chosen to select the data below.

We included the following covariates to compare vaccinated to nonvaccinated patients:

- At diagnosis: age, gender, and complementary universal health insurance (CMU-C). In France, this supplementary insurance is available free of charge for people with a low income who are entitled to universal healthcare coverage.

- During the observation period: Comorbidities were assessed by calculating a SNDS database adaptation of the Charlson Comorbidity Index [22-24]. We used the Charlson items and French recommendations for $S P$ vaccination [25] to identify patients with a dual recommendation for $S P$ vaccination (MM and another disease). We also included the healthcare consumption profile: number of different drugs used (categorized as ATC classes), number of different drugs used excluding vaccines (categorized as ATC classes), reimbursed vaccines (none versus at least one), number of medical visits (as a continuous variable), and number of hospital stays (none versus 
at least one). Lastly, we included two socioeconomic variables calculated using the community (smallest administrative unit in France) code [26]: the patient geographic area (urban versus rural) and the Fdep09, a deprivation index [27], with patients in the fifth quintile being the most deprived.

- During the study period: antiviral prophylaxis (Herpes simplex virus (HSV) and Varicellazoster-virus (VZV)) with at least two valaciclovir (ATC code J05AB11) reimbursements and Pneumocystis jirovecii prophylaxis with at least two cotrimoxazole (ATC code J01EE01) or two pentamidine (ATC code P01CX01) reimbursements.

\subsection{Analyses}

Sociodemographic and medical characteristics of patients were described according to vaccinations (all three vaccines, SP or Hib vaccine, and no vaccine). Qualitative variables were expressed in frequencies and percentages and compared using the chi-squared test or Fisher's exact test. Quantitative variables were expressed as mean and standard deviation (or median and interquartile range (IQR), if relevant) and associations were determined using the Student's $t$-test or Wilcoxon test (if the variable was not normally distributed). All tests with a two-sided $p$ value $<0.05$ were considered significant.

For each of the vaccines considered, we recorded the date of dispensing as the date of vaccination. We then categorized vaccination dates in three periods: the first year after MM diagnosis, between the first and the second year after MM diagnosis, or between MM diagnosis and 2 years after, as there is no recommended vaccination period in the IMWG guidelines [13].

Factors associated with vaccination were examined using a logistic regression model with a backward stepwise elimination process. Age and gender were variables forced in the initial model. Factors associated with vaccination in bivariate analysis $(p<0.25)$ were included in the initial model (factors among: Charlson Comorbidity Index, SP vaccination recommended, Fdep99 deprivation index, complementary universal health insurance, geographic area, number of medical visits during observation, patients with at least one hospital stay during observation, number of nonvaccine drugs used during observation, patients vaccinated during observation, HSV-VZV prophylaxis during study, and P. Jirovecii prophylaxis during study). Potential multicollinearity was examined based on Besley's criteria. The final model only retained statistically significant variables $(p<0.05)$. The goodness of fit of the final model was evaluated with the Hosmer-Lemeshow test and considered acceptable if the $p$-value was $<0.05$.

All data analyses were carried out with SAS 9.4 software (SAS Institute, Cary, NC, USA).

\section{Results}

\subsection{Characteristics of MM Patients}

From 1 January 2010 to 31 December 2013, 36,990 subjects presented at least one MM ICD-10 code in France. After exclusion of prevalent cases, 22,831 MM cases were identified as incident (Figure 2). The median age was 74 years (IQR 64-82), with 11,797 (51.7\%) male patients. During the 24-month study period, 3461 (15.2\% of newly diagnosed patients) deaths occurred with 2352 (10.3\% of newly diagnosed patients) deaths during the first year after MM diagnosis. Sociodemographic and medical characteristics, according to our primary outcome during the study period, are presented in Table 1. With respect to our secondary outcome, the same characteristics are presented in Table 2. 


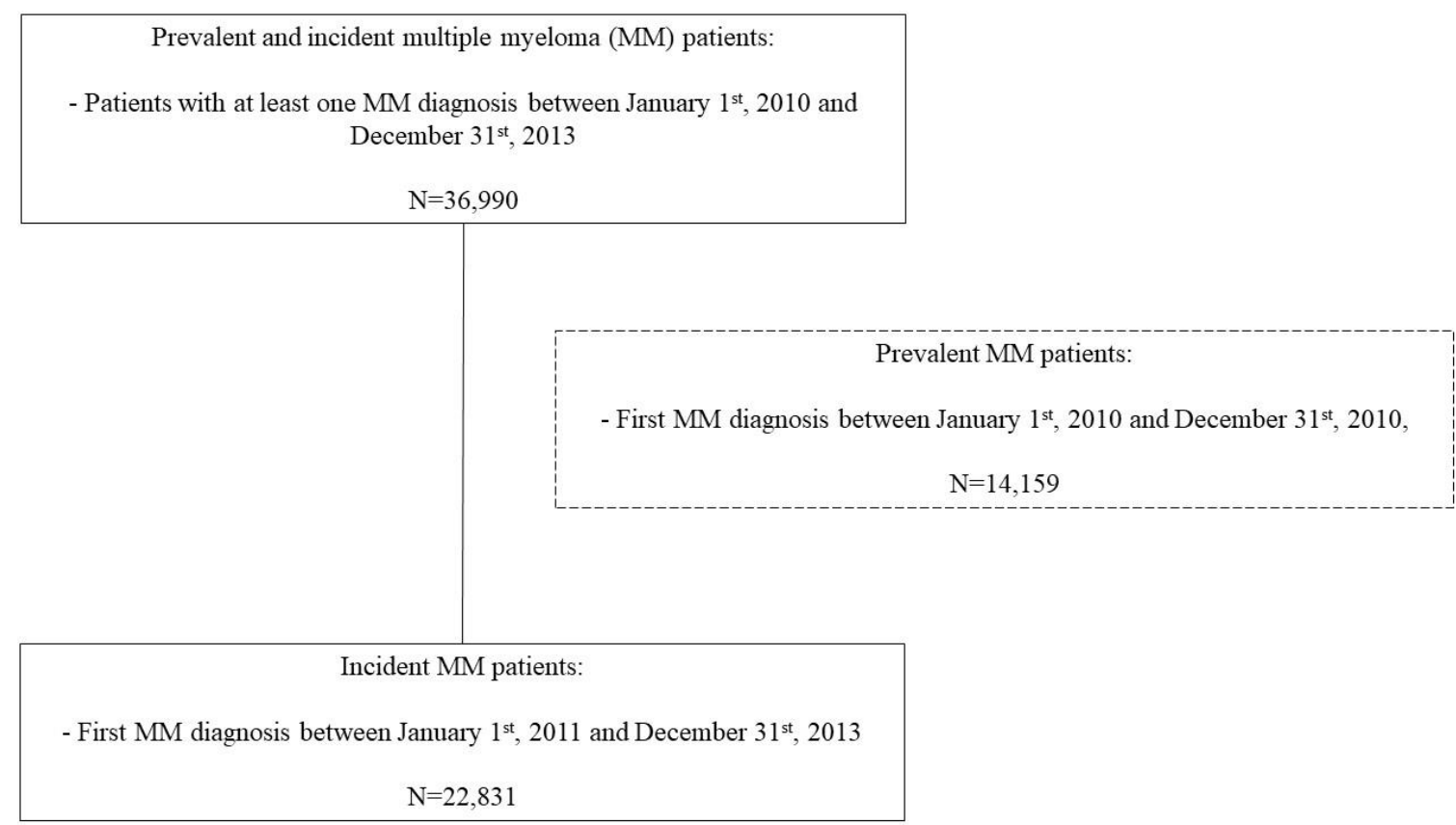

Figure 2. Flowchart of patients included in the study.

Table 1. Sociodemographic and medical characteristics of patients during the observation period (12 months before multiple myeloma (MM) diagnosis)—primary outcome.

\begin{tabular}{|c|c|c|c|c|}
\hline \multirow[b]{2}{*}{ Characteristics } & \multirow{2}{*}{$\begin{array}{c}\text { Total } \\
\text { Population }\end{array}$} & \multicolumn{2}{|c|}{ Primary Outcome } & \multirow[b]{2}{*}{$p$-Value } \\
\hline & & $\begin{array}{l}\text { Not All Recommended } \\
\text { Vaccines }\end{array}$ & $\begin{array}{l}\text { Influenza and } \\
S P \text { and } H i b\end{array}$ & \\
\hline Number of subjects, $n(\%)$ & 22,831 & $22,679(99.3)$ & $152(0.7)$ & \\
\hline Age (years), median (IQR) & $74(64-82)$ & $74(64-82)$ & $66(62-75)$ & $<0.0001$ \\
\hline Females, $n(\%)$ & $11,034(48.3)$ & $10,964(48.3)$ & $70(46.1)$ & 0.5731 \\
\hline Charlson Comorbidity Index, $n(\%)$ & & & & 0.0418 \\
\hline 0 & $11,632(50.9)$ & $11,540(50.9)$ & $92(60.5)$ & \\
\hline $1-2$ & $6737(29.5)$ & $6696(29.5)$ & $41(27.0)$ & \\
\hline $3-4$ & $2119(9.3)$ & $2113(9.3)$ & $6(3.9)$ & \\
\hline$\geq 5$ & $2343(10.3)$ & $2330(10.3)$ & $13(8.6)$ & \\
\hline $\begin{array}{l}S P \text { vaccination recommendation not } \\
\text { related to } \mathrm{MM}, n(\%)\end{array}$ & $11,099(48.6)$ & $11,028(48.6)$ & $71(46.7)$ & 0.6376 \\
\hline Fdep99 deprivation index, $n(\%)$ & & & & 0.4765 \\
\hline 1st quintile & $4213(18.4)$ & $4180(18.4)$ & $33(21.6)$ & \\
\hline 2nd quintile & $4067(17.8)$ & $4040(17.8)$ & $27(17.8)$ & \\
\hline 3rd quintile & $4145(18.2)$ & $4117(18.1)$ & $28(18.4)$ & \\
\hline 4th quintile & $4281(18.8)$ & $4254(18.8)$ & $27(17.8)$ & \\
\hline 5th quintile & $4264(18.7)$ & $4233(18.7)$ & $31(20.4)$ & \\
\hline Unknown & $1861(8.1)$ & $1855(8.2)$ & $6(4.0)$ & \\
\hline $\begin{array}{l}\text { Complementary universal health } \\
\text { insurance (CMU-C), } n(\%)\end{array}$ & $1285(5.6)$ & $1279(5.6)$ & $6(4.0)$ & 0.3669 \\
\hline Geographic area, $n(\%)$ & & & & 0.9821 \\
\hline Urban & $13,008(57.0)$ & $12,921(57.0)$ & $87(57.2)$ & \\
\hline Rural & $4491(19.7)$ & $4462(19.7)$ & $29(19.1)$ & \\
\hline Unknown & $5332(23.3)$ & $5296(23.3)$ & $36(23.7)$ & \\
\hline Number of medical visits, median (IQR) & $13(8-19)$ & $13(8-19)$ & $12.5(8-17)$ & 0.1336 \\
\hline $\begin{array}{l}\text { Patients with at least one hospital stay, } \\
\qquad n(\%)\end{array}$ & 8579 (37.6) & 8528 (37.6) & 51 (33.6) & 0.3041 \\
\hline $\begin{array}{l}\text { Number of drugs used, excluding } \\
\text { vaccines, median (IQR) }\end{array}$ & $17(11-24)$ & $17(11-24)$ & $17(12.5-23)$ & 0.5273 \\
\hline Vaccinated patients, $n(\%)$ & $9587(42.0)$ & $9946(41.9)$ & $91(59.9)$ & $<0.0001$ \\
\hline
\end{tabular}


Table 2. Sociodemographic and medical characteristics of patients during the observation period (12 months before MM diagnosis)—secondary outcome.

\begin{tabular}{|c|c|c|c|c|}
\hline \multirow{2}{*}{ Characteristics } & \multirow{2}{*}{ Total Population } & \multicolumn{2}{|c|}{ Secondary Outcome } & \multirow[t]{2}{*}{$p$-Value } \\
\hline & & No $\mathrm{SP}$ or $\mathrm{Hib}$ & SP or $\mathrm{Hib}$ & \\
\hline Number of subjects, $n(\%)$ & 22,831 & $20,466(89.6)$ & $2365(10.4)$ & \\
\hline Age (years), median (IQR) & $74(64-82)$ & $75(64-82)$ & $67(60-77)$ & $<0.0001$ \\
\hline Females, n (\%) & $11,034(48.3)$ & $9965(48.7)$ & $1069(45.2)$ & 0.0013 \\
\hline Charlson Comorbidity Index, $n(\%)$ & & & & $<0.0001$ \\
\hline 0 & $11,632(50.9)$ & $10,249(50.1)$ & $1383(58.5)$ & \\
\hline $1-2$ & $6737(29.5)$ & $6086(29.7)$ & $651(27.5)$ & \\
\hline $3-4$ & $2119(9.3)$ & $1984(9.7)$ & $135(5.7)$ & \\
\hline$\geq 5$ & $2343(10.3)$ & $2147(10.5)$ & $196(8.3)$ & \\
\hline$S P$ vaccination recommendation not related to $\mathrm{MM}, n(\%)$ & $11,099(48.6)$ & $10,090(49.3)$ & $1009(42.7)$ & $<0.0001$ \\
\hline Fdep 99 deprivation index, $n(\%)$ & & & & $<0.0001$ \\
\hline 1st quintile & $4213(18.4)$ & $3722(18.2)$ & $491(20.8)$ & \\
\hline 2nd quintile & $4067(17.8)$ & $3609(17.6)$ & $458(19.4)$ & \\
\hline 3rd quintile & $4145(18.2)$ & $3677(18.0)$ & $468(19.8)$ & \\
\hline 4th quintile & $4281(18.8)$ & $3832(18.7)$ & $449(19.0)$ & \\
\hline 5th quintile & $4264(18.7)$ & $3863(18.9)$ & $401(16.9)$ & \\
\hline Unknown & $1861(8.1)$ & $1763(8.6)$ & $98(4.1)$ & \\
\hline Complementary universal health insurance, $n(\%)$ & $1285(5.6)$ & $1158(5.7)$ & $127(5.4)$ & 0.5648 \\
\hline Geographic area, $n(\%)$ & & & & 0.0003 \\
\hline Urban & $13,008(57.0)$ & $11,745(57.4)$ & $1263(53.4)$ & \\
\hline Rural & $4491(19.7)$ & 4011 (19.6) & $480(20.3)$ & \\
\hline Unknown & $5332(23.3)$ & $4710(23.0)$ & $622(26.3)$ & \\
\hline Number of medical visits, median (IQR) & $13(8-19)$ & $13(8-19)$ & $12.5(8-18)$ & 0.0025 \\
\hline Patients with at least one hospital stay, $n(\%)$ & $8579(37.6)$ & $7811(38.2)$ & $768(32.5)$ & $<0.0001$ \\
\hline Number of drugs used, median (IQR) & $18(12-25)$ & $18(12-24)$ & $18(12-25)$ & 0.0015 \\
\hline Number of drugs used, excluding vaccines, median (IQR) & $17(11-24)$ & $17(11-24)$ & $18(12-24)$ & 0.0017 \\
\hline Vaccinated patients, $n(\%)$ & $9587(42.0)$ & $8550(41.8)$ & $1037(43.9)$ & 0.0533 \\
\hline
\end{tabular}

\subsection{Vaccine Use in MM Patients}

Among the 22,831 newly diagnosed MM patients (Table 3), 6517 (28.5\%) had at least one reimbursement for an influenza vaccine in year one after diagnosis and $5960(26.1 \%)$ during year two after MM diagnosis. Regarding the SP vaccine, 1353 patients (5.9\%) had at least one reimbursement during year one after MM diagnosis. All in all, during the 2 years after MM diagnosis, $S P$ vaccination was initiated for $2350(10.3 \%)$ patients. Moreover, 199 patients $(0.9 \%)$ had an Hib vaccine reimbursement in year one after MM diagnosis and a total of $316(1.4 \%)$ had an Hib vaccine reimbursement during the 2 years after MM diagnosis.

Table 3. Details of vaccinated patients for the study period (24 months after MM diagnosis).

\begin{tabular}{cccc}
\hline \multirow{2}{*}{ Vaccinated Patients, $\boldsymbol{n}$ (\%) } & \multicolumn{3}{c}{ Time after MM Diagnosis } \\
\cline { 2 - 4 } & 0-12 Months & 12-24 Months & 0-24 Months \\
\hline Against influenza & $6517(28.5)$ & $5960(26.1)$ & $8000(35.1)$ \\
Against S.p. & $1353(5.9)$ & $1149(5.0)$ & $2350(10.3)$ \\
Against H.i.b. & $199(0.9)$ & $125(0.6)$ & $316(1.4)$ \\
\hline
\end{tabular}

S.p: Streptococcus pneumoniae; H.i.b.: Hemophilus influenzae b; MM: multiple myeloma.

\subsection{Factors Associated with Vaccination}

Tables 4 and 5 present the results of the bivariate and multivariate logistic regression models for the primary and secondary outcome, respectively.

Regarding our primary outcome, young age, vaccination during the observation period, and HSV-VZV or P. Jirovecii prophylaxis during the study period were associated with influenza, $S P$, and $H i b$ vaccinations during the study period in the bivariate analyses. These associations persisted in the multivariate model. 
Regarding our secondary outcome in the multivariate model, SP or Hib vaccination during the study period was associated with young age, male sex, an absence of comorbidities, an absence of medical consultations or hospitalizations, medication consumption and vaccinations during the observation period, and HSV-VZV or P. Jirovecii prophylaxis during the study period.

Table 4. Logistic regression model for factors associated with vaccination against influenza, $S P$, and $H i b$ during the study period-primary outcome.

\begin{tabular}{|c|c|c|c|c|}
\hline Characteristics & $\begin{array}{l}\text { Crude OR } \\
(95 \% \text { CI })\end{array}$ & $p$-Value & $\begin{array}{l}\text { Adjusted OR } \\
(95 \% \mathrm{CI})\end{array}$ & $p$-Value \\
\hline Age (year) & $0.97(0.96-0.98)$ & $<0.0001$ & $0.98(0.97-0.99)$ & 0.0132 \\
\hline Female gender & $0.91(0.66-1.26)$ & 0.5732 & $1.00(0.73-1.39)$ & 0.9853 \\
\hline Charlson Comorbidity Index & & 0.0507 & - & - \\
\hline 0 & 1 & & & \\
\hline $1-2$ & $0.77(0.53-1.11)$ & & & \\
\hline $3-4$ & $0.36(0.16-0.82)$ & & & \\
\hline$\geq 5$ & $0.70(0.39-1.25)$ & & & \\
\hline$S P$ vaccination recommended & $0.93(0.67-1.28)$ & 0.6377 & - & - \\
\hline Fdep99 deprivation index & & 0.5024 & - & - \\
\hline 1st quintile & 1 & & & \\
\hline 2nd quintile & $0.85(0.51-1.41)$ & & & \\
\hline 3rd quintile & $0.86(0.52-1.43)$ & & & \\
\hline 4th quintile & $0.80(0.48-1.34)$ & & & \\
\hline 5 th quintile & $0.93(0.57-1.52)$ & & & \\
\hline Unknown & $0.41(0.17-0.98)$ & & & \\
\hline Complementary universal health insurance & $0.69(0.30-1.56)$ & 0.3697 & - & - \\
\hline Geographic area & & 0.9824 & - & - \\
\hline Urban & 1 & & & \\
\hline Rural & $0.97(0.63-1.47)$ & & & \\
\hline Unknown & $1.01(0.68-1.49)$ & & & \\
\hline Number of medical visits during observation & $0.99(0.98-1.01)$ & 0.4251 & - & - \\
\hline $\begin{array}{l}\text { Patients with at least one hospital } \\
\text { stay during observation }\end{array}$ & $0.84(0.60-1.18)$ & 0.3048 & - & - \\
\hline $\begin{array}{l}\text { Number of nonvaccine drugs } \\
\text { used during observation }\end{array}$ & $1.01(0.99-1.02)$ & 0.4004 & - & - \\
\hline Patients vaccinated during observation & $2.07(1.50-2.87)$ & $<0.0001$ & $3.00(2.11-4.25)$ & $<0.0001$ \\
\hline HSV-VZV prophylaxis during study & $5.87(3.94-8.76)$ & $<0.0001$ & $3.15(1.93-5.14)$ & $<0.0001$ \\
\hline P. Jirovecii prophylaxis during study & $5.11(3.67-7.11)$ & $<0.0001$ & $2.55(1.70-3.80)$ & $<0.0001$ \\
\hline
\end{tabular}

$\mathrm{CI}$ confidence interval, OR odds ratio. Logistic regression model adjusted for age, female gender, patients vaccinated during observation, HSV-VZV prophylaxis during study, and P. Jirovecii prophylaxis during study.

Table 5. Logistic regression model for factors associated with vaccination against SP or Hib during the study period-secondary outcome.

\begin{tabular}{|c|c|c|c|c|}
\hline Characteristics & $\begin{array}{c}\text { Crude OR } \\
(95 \% \text { CI })\end{array}$ & $p$ Value & $\begin{array}{l}\text { Adjusted OR } \\
(95 \% \text { CI })\end{array}$ & $p$ Value \\
\hline Age (year) & $\begin{array}{c}0.970 \\
(0.967-0.974)\end{array}$ & $<0.0001$ & $0.98(0.97-0.99)$ & $<0.0001$ \\
\hline Female gender & $0.87(0.80-0.95)$ & 0.0013 & $0.91(0.83-0.99)$ & 0.0324 \\
\hline Charlson Comorbidity Index & & $<0.0001$ & & 0.0448 \\
\hline 0 & 1 & & 1 & \\
\hline $1-2$ & $0.79(0.72-0.88)$ & & $1.00(0.90-1.11)$ & \\
\hline $3-4$ & $0.50(0.42-0.61)$ & & $0.83(0.68-1.00)$ & \\
\hline$\geq 5$ & $0.68(0.58-0.79)$ & & $0.84(0.71-0.98)$ & \\
\hline$S P$ vaccination recommended & $0.77(0.70-0.84)$ & $<0.0001$ & - & - \\
\hline Fdep99 deprivation index & & $<0.0001$ & & $<0.0001$ \\
\hline 1st quintile & 1 & & 1 & \\
\hline 2nd quintile & $0.96(0.84-1.10)$ & & $0.97(0.85-1.11)$ & \\
\hline
\end{tabular}


Table 5. Cont.

\begin{tabular}{|c|c|c|c|c|}
\hline Characteristics & $\begin{array}{l}\text { Crude OR } \\
(95 \% \text { CI })\end{array}$ & $p$ Value & $\begin{array}{l}\text { Adjusted OR } \\
\quad(95 \% \mathrm{CI})\end{array}$ & $p$ Value \\
\hline 3rd quintile & $0.97(0.84-1.10)$ & & $1.03(0.90-1.18)$ & \\
\hline 4th quintile & $0.89(0.78-1.02)$ & & $0.96(0.84-1.11)$ & \\
\hline 5 th quintile & $0.79(0.69-0.91)$ & & $0.87(0.75-1.00)$ & \\
\hline Unknown & $0.42(0.34-0.53)$ & & $0.54(0.43-0.68)$ & \\
\hline Complementary universal health insurance & $0.95(0.78-1.14)$ & 0.5648 & - & - \\
\hline Geographic area & & 0.0003 & - & - \\
\hline Urban & 1 & & & \\
\hline Rural & $1.11(1.00-1.24)$ & & & \\
\hline Unknown & $1.23(1.11-1.36)$ & & & \\
\hline Number of medical visits during observation & $1.00(0.99-1.00)$ & 0.2455 & $0.99(0.98-1.00)$ & 0.0226 \\
\hline $\begin{array}{l}\text { Patients with at least one hospital } \\
\text { stay during observation }\end{array}$ & $0.78(0.71-0.85)$ & $<0.0001$ & $0.89(0.81-0.99)$ & 0.0256 \\
\hline $\begin{array}{c}\text { Number of nonvaccine drugs } \\
\text { used during observation }\end{array}$ & $1.01(1.00-1.01)$ & 0.0003 & $1.01(1.00-1.02)$ & 0.0002 \\
\hline Patients vaccinated during observation & $1.09(1.00-1.19)$ & 0.0534 & $1.39(1.26-1.53)$ & $<0.0001$ \\
\hline HSV-VZV prophylaxis during study & $3.01(2.75-3.29)$ & $<0.0001$ & $2.11(1.89-2.36)$ & $<0.0001$ \\
\hline P. Jirovecii prophylaxis during study & $2.44(2.23-2.66)$ & $<0.0001$ & $1.27(1.14-1.41)$ & $<0.0001$ \\
\hline
\end{tabular}

CI confidence interval, OR odds ratio. Logistic regression model adjusted for age, female gender, Charlson Comorbidity Index, Fdep99 deprivation index, number of medical visits during observation, patients with at least one hospital stay during observation, number of nonvaccine drugs used during observation, patients vaccinated during observation, HSV-VZV prophylaxis during study, and P. Jirovecii prophylaxis during study.

\section{Discussion}

Our study shows that the percentage of patients vaccinated for the 3 recommended vaccines is very low $(0.7 \%)$. Patients vaccinated for Streptococcus pneumoniae (SP) or for Hemophilus influenzae b (Hib) represent only $10.4 \%$ of our sample. This first nationwide study indicates a low rate of MM patients vaccinated against influenza, $S P$, and $H i b$ in France despite the publication of guidelines.

In the 2 years following MM diagnosis, only $0.7 \%$ of the patients had at least one reimbursement for all three recommended vaccines. Vaccination rates for influenza in year one and year two after MM diagnosis were $28.5 \%$ and $26.1 \%$, respectively. During the 2 years following MM diagnosis, $10.3 \%$ of the patients had at least one SP vaccine reimbursement and $1.4 \%$ of the patients had at least one Hib vaccine reimbursement.

One small retrospective American study with 411 MM patients from 2012 to 2014 found that $58 \%$ had received at least one SP vaccine [28]. To our knowledge, this is the only other study of vaccination rates in MM patients. Two other studies used the SNDS to assess vaccination rates in immunocompromised patients. The first involved 423 idiopathic thrombocytopenic purpura patients and showed that $32.4 \%$ of the patients were vaccinated against SP and $18.9 \%$ against Hib [29]. The second-known study included 101 patients with moderate to severe psoriasis treated with a biological drug and showed vaccination rates of $17.8 \%$ and $14.9 \%$ for influenza and SP, respectively [30]. Our vaccination rates are lower than in the previously cited articles. Considering that most of our patients were 70 years of age or older with comorbidities, we might have missed $S P$ or Hib vaccination before MM diagnosis. Our influenza vaccination rates are also low (yearly rate of 26-29\%) and therefore consistent throughout.

Overall, these results underscore that physician and patient adherence or education regarding vaccination is quite poor in France. Despite the fact that there is no clear data on the clinical impact of these vaccinations [31], it could be argued that this population is exposed to many disease and treatment-related risk factors of life-threatening infections and should be better protected.

It is interesting to note that in this study, we also found that young age, an absence of comorbidity, a higher consumption of medications including vaccines, HSV-VZV and pneumocystis prophylaxis were associated with higher rates of vaccination. It indicates that oddly enough, patients with a 
lower risk of life-threatening infections are more likely to be vaccinated. In contrast, patients with comorbidities who often consult physicians and who have a history of hospitalizations are less likely to be vaccinated, despite more significant benefits of vaccination in this population. This might be due to the fact that better attention is paid to younger and healthier patients with a longer life expectancy. We can assume that people who are more health conscious are less likely to have comorbidity and are more likely to get vaccinated. These patient profiles may be more favorable to be vaccinated, or it is these patients who are more favorably offered to be vaccinated.

Another explanation could be a measurement bias if older hospitalized patients were vaccinated during hospitalization as we could not account for in-hospital vaccination. However, this seems to be rare, because in France, vaccinations are entrusted to general practitioners [29]. There is also no guideline for in-hospital vaccination in France [29].

The patient's geographic area of residence does not seem to be influenced by the analysis of the primary outcome. As the result is not significant, it is not possible to know if it is by an absence of effect or if it is by a lack of potency (152 patients among the 22,679 met the main endpoint). On the secondary objective, in univariate analysis, patients living in rural areas seem to be more likely to be vaccinated. Is it because of care in smaller health establishments or is it specifically associated with the place of residence? Further studies are needed to analyze this effect more precisely. Likewise, it would be very interesting to study whether there is heterogeneity between the different regions of French territory. Here too, further studies are necessary in order to be able to properly study this question.

Our study has some limitations that should be discussed. Because it was a study conducted using a health insurance database, identification of MM patients relied on ICD-10 codes. The possibility of miscoding cannot be fully excluded [32,33]. The algorithm we used to detect incident MM cases is also not flawless despite having a sensitivity and specificity of $90.4 \%$ and $99.7 \%$, respectively [19]. Two factors might also have led to an underestimation of vaccine exposure. First, we could not obtain information regarding the 5 years prior to $\mathrm{MM}$ diagnosis. As a result, patients vaccinated before $\mathrm{MM}$ diagnosis might have been misclassified as nonvaccinated. However, $S P$ and $H i b$ vaccines are only recommended in France for infants under 18 months of age [34]. They are also recommended in case of risk factors for invasive SP or Hib infections such as immunodeficiency and chronic diseases [25]. There are concerns about the long-term effectiveness of these vaccines [35]. Consequently, revaccination is recommended when the previous dose of $S P$ vaccine was administered more than 5 years earlier (10 years for $\mathrm{Hib}$ ) [36]. We also might have underestimated vaccine exposure when patients had a chronic disease requiring SP vaccination in the 5 years prior to MM diagnosis. Considering that almost half of our patients had a condition requiring vaccination against $S P$, our results regarding this specific vaccine might have been altered. Second and as discussed previously, we only assessed vaccine exposure through hospital vaccine reimbursement.

Lastly, the French policy for $S P$ vaccination changed during the study period and now recommends a prime-boost strategy with a pneumococcal polysaccharide vaccine first, followed by a pneumococcal conjugate vaccine 8 weeks later [25]. The impact of this modification in clinical practice remains unknown. Therefore, large pharmacoepidemiological studies to assess the clinical impact of these vaccinations in this population of patients would be welcomed.

\section{Conclusions}

All things considered, this study highlights insufficient rates of recommended vaccinations in French MM patients. More attention should be paid to appropriate vaccination, starting during smoldering MM as the highest antibody responses are obtained in patients vaccinated in the early stages of the disease (before initiation of chemotherapy and advanced hypogammaglobulinemia) [37]. Further assessments of this type in different countries would identify whether this problem is observed elsewhere. Studies evaluating the impact of measures to encourage the use of vaccination would make it possible to better target patient profiles for whom particular attention should be paid. 
Author Contributions: Conceptualization, F.D. and M.L.-M.; methodology, C.C., F.D., and M.L.-M.; software, G.T. and C.C.; validation, G.T., C.C., A.P., F.D., and M.L.-M.; formal analysis, G.T. and C.C.; data curation, G.T. and C.C.; writing-original draft preparation, G.T. and C.C.; writing-review and editing, A.P., F.D., and M.L.M.; supervision, F.D. and M.L.-M. All authors have read and agreed to the published version of the manuscript.

Funding: This work received support from the National Research Agency (Agence Nationale de la Recherche (ANR)) for the "investissement d'avenir" ("Investment in the Future") (ANR-11-PHUC-001). This academic study was supported by a public grant from the Groupement Interrégional de Recherche Clinique et d'Innovation Sud-Ouest Outre-Mer Hospitalier (APITHEM 2016).

Conflicts of Interest: The authors declare that they have no conflict of interest.

\section{References}

1. Kumar, S.K.; Dispenzieri, A.; Lacy, M.Q.; Gertz, M.A.; Buadi, F.K.; Pandey, S.; Kapoor, P.; Dingli, D.; Hayman, S.R.; Leung, N.; et al. Continued improvement in survival in multiple myeloma: Changes in early mortality and outcomes in older patients. Leukemia 2014, 28, 1122-1128. [CrossRef] [PubMed]

2. Kristinsson, S.Y.; Anderson, W.F.; Landgren, O. Improved long-term survival in multiple myeloma up to the age of 80 years. Leukemia 2014, 28, 1346-1348. [CrossRef] [PubMed]

3. Kristinsson, S.Y.; Landgren, O.; Dickman, P.W.; Derolf, A.R.; Björkholm, M. Patterns of survival in multiple myeloma: A population-based study of patients diagnosed in Sweden from 1973 to to 2003. J. Clin. Oncol. Off. J. Am. Soc. Clin. Oncol. 2007, 25, 1993-1999. [CrossRef] [PubMed]

4. Palumbo, A.; Mina, R. Management of older adults with multiple myeloma. Blood Rev. 2013, 27, $133-142$. [CrossRef]

5. Kyle, R.A.; Rajkumar, S.V. Multiple myeloma. N. Engl. J. Med. 2004, 351, 1860-1873. [CrossRef]

6. Nucci, M.; Anaissie, E. Infections in patients with multiple myeloma in the era of high-dose therapy and novel agents. Clin. Infect. Dis. Off. Publ. Infect. Dis. Soc. Am. 2009, 49, 1211-1225. [CrossRef]

7. Blimark, C.; Holmberg, E.; Mellqvist, U.-H.; Landgren, O.; Björkholm, M.; Hultcrantz, M.; Kjellander, C.; Turesson, I.; Kristinsson, S.Y. Multiple myeloma and infections: A population-based study on 9253 multiple myeloma patients. Haematologica 2015, 100, 107-113. [CrossRef]

8. Pratt, G.; Goodyear, O.; Moss, P. Immunodeficiency and immunotherapy in multiple myeloma. Br. J. Haematol. 2007, 138, 563-579. [CrossRef]

9. Gregersen, H.; Madsen, K.M.; Sørensen, H.T.; Schønheyder, H.C.; Ibsen, J.S.; Dahlerup, J.F. The risk of bacteremia in patients with monoclonal gammopathy of undetermined significance. Eur. J. Haematol. 1998, 61, 140-144. [CrossRef]

10. Kristinsson, S.Y.; Tang, M.; Pfeiffer, R.M.; Björkholm, M.; Goldin, L.R.; Blimark, C.; Mellqvist, U.-H.; Wahlin, A.; Turesson, I.; Landgren, O. Monoclonal gammopathy of undetermined significance and risk of infections: A population-based study. Haematologica 2012, 97, 854-858. [CrossRef]

11. Hargreaves, R.M.; Lea, J.R.; Griffiths, H.; Faux, J.A.; Holt, J.M.; Reid, C.; Bunch, C.; Lee, M.; Chapel, H.M. Immunological factors and risk of infection in plateau phase myeloma. J. Clin. Pathol. 1995, 48, 260-266. [CrossRef] [PubMed]

12. Karlsson, J.; Andréasson, B.; Kondori, N.; Erman, E.; Riesbeck, K.; Hogevik, H.; Wennerås, C. Comparative study of immune status to infectious agents in elderly patients with multiple myeloma, Waldenstrom's macroglobulinemia, and monoclonal gammopathy of undetermined significance. Clin. Vaccine Immunol. CVI 2011, 18, 969-977. [CrossRef]

13. Ludwig, H.; Miguel, J.S.; Dimopoulos, M.A.; Palumbo, A.; Garcia Sanz, R.; Powles, R.; Lentzsch, S.; Chen, W.M.; Hou, J.; Jurczyszyn, A.; et al. International Myeloma Working Group recommendations for global myeloma care. Leukemia 2014, 28, 981-992. [CrossRef] [PubMed]

14. Robertson, J.D.; Nagesh, K.; Jowitt, S.N.; Dougal, M.; Anderson, H.; Mutton, K.; Zambon, M.; Scarffe, J.H. Immunogenicity of vaccination against influenza, Streptococcus pneumoniae and Haemophilus influenzae type B in patients with multiple myeloma. Br. J. Cancer 2000, 82, 1261-1265. [CrossRef] [PubMed]

15. Rajkumar, S.V.; Gertz, M.A.; Kyle, R.A.; Greipp, P.R.; Myeloma, M.C. Current therapy for multiple myeloma. Mayo Clin. Proc. 2002, 77, 813-822. [CrossRef] [PubMed] 
16. Ludwig, H.; Delforge, M.; Facon, T.; Einsele, H.; Gay, F.; Moreau, P.; Avet-Loiseau, H.; Boccadoro, M.; Hajek, R.; Mohty, M.; et al. Prevention and management of adverse events of Novel agents in multiple myeloma: A consensus of the european myeloma network. Leukemia 2018, 32, 1542-1560. [CrossRef] [PubMed]

17. Moulis, G.; Lapeyre-Mestre, M.; Palmaro, A.; Pugnet, G.; Montastruc, J.-L.; Sailler, L. French health insurance databases: What interest for medical research? Rev. Med. Interne. 2015, 36, 411-417. [CrossRef]

18. Conte, C.; Rueter, M.; Laurent, G.; Bourrel, R.; Lapeyre-Mestre, M.; Despas, F. Psychotropic drug initiation during the first diagnosis and the active treatment phase of B cell non-Hodgkin's lymphoma: A cohort study of the French national health insurance database. Support. Care Cancer Off. J. Multinatl. Assoc. Support. Care Cancer 2016, 24, 4791-4799. [CrossRef]

19. Palmaro, A.; Gauthier, M.; Conte, C.; Grosclaude, P.; Despas, F.; Lapeyre-Mestre, M. Identifying multiple myeloma patients using data from the French health insurance databases: Validation using a cancer registry. Medicine 2017, 96, e6189. [CrossRef]

20. HCSP. Actualisation de la Liste des Sujets Eligibles à la Vaccination Contre la Grippe Saisonnière; Haut Conseil de la Santé Publique: Paris, France, 2010; Available online: https://www.hcsp.fr/Explore.cgi/avisrapportsdomaine? clefr $=179$ (accessed on 14 December 2018).

21. WHOCC_ATC/DDD Index. Available online: https://www.whocc.no/atc_ddd_index/ (accessed on 31 January 2019).

22. Charlson, M.E.; Pompei, P.; Ales, K.L.; MacKenzie, C.R. A new method of classifying prognostic comorbidity in longitudinal studies: Development and validation. J. Chronic Dis. 1987, 40, 373-383. [CrossRef]

23. Bannay, A.; Chaignot, C.; Blotière, P.-O.; Weill, A.; Ricordeau, P.; Alla, F. Score de Charlson à partir des données du Sniiram chaînées au PMSI: Faisabilité et valeur pronostique sur la mortalité à un an. Rev. DÉpidémiologie Santé Publique 2013, 61, S9. [CrossRef]

24. Bannay, A.; Chaignot, C.; Blotière, P.-O.; Basson, M.; Weill, A.; Ricordeau, P.; Alla, F. The Best Use of the Charlson Comorbidity Index With Electronic Health Care Database to Predict Mortality. Med. Care 2016, 54, 188-194. [CrossRef] [PubMed]

25. HCSP. Infections Invasives A Pneumocoque: Recommandations Vaccinales Pour les Personnes à Risque; Haut Conseil de la Santé Publique: Paris, France, 2013; Available online: https://www.hcsp.fr/Explore.cgi/ avisrapportsdomaine? clefr=355 (accessed on 17 September 2018).

26. Codes Géographiques et Codes Pays | Publication ATIH. Available online: https://www.atih.sante.fr/codesgeographiques-et-codes-pays (accessed on 28 May 2018).

27. Rey, G.; Jougla, E.; Fouillet, A.; Hémon, D. Ecological association between a deprivation index and mortality in France over the period 1997-2001: Variations with spatial scale, degree of urbanicity, age, gender and cause of death. BMC Public Health 2009, 9, 33. [CrossRef] [PubMed]

28. Alemu, A.; Singh, M.; Blumberg, C.; Richards, J.; Oaks, M.; Thompson, M. Multiple Myeloma Vaccination Patterns in a Large Health System: A Pilot Study. J. Patient-Cent. Res. Rev. 2017, 4, 53-59. [CrossRef] [PubMed]

29. Moulis, G.; Lapeyre-Mestre, M.; Mahévas, M.; Montastruc, J.-L.; Sailler, L. Need for an improved vaccination rate in primary immune thrombocytopenia patients exposed to rituximab or splenectomy. A nationwide population-based study in France. Am. J. Hematol. 2015, 90, 301-305. [CrossRef] [PubMed]

30. Couderc, S. Risque Infectieux des Medicaments Biologiques Versus Traitements Systemiques Conventionnels Dans le Psoriasis Modere a Severe = Infectious Risk of Biological Drugs Versus Conventional Systemic Treatements in Moderate to Severe Psoriasis, Limoges, 2015. Available online: http://aurore.unilim.fr/ori-oaisearch/notice/view/unilim-ori-53243 (accessed on 6 May 2019).

31. Alemu, A.; Richards, J.O.; Oaks, M.K.; Thompson, M.A. Vaccination in Multiple Myeloma: Review of Current Literature. Clin. Lymphoma Myeloma Leuk. 2016, 16, 495-502. [CrossRef]

32. Moulis, G.; Palmaro, A.; Montastruc, J.-L.; Godeau, B.; Lapeyre-Mestre, M.; Sailler, L. Epidemiology of incident immune thrombocytopenia: A nationwide population-based study in France. Blood 2014, 124, 3308-3315. [CrossRef]

33. Moulis, G.; Sailler, L.; Adoue, D.; Lapeyre-Mestre, M. Pharmacoepidemiology of Immune Thrombocytopenia: Protocols of FAITH and CARMEN studies. Therapie 2014, 69, 437-448. [CrossRef]

34. INPES -Calendrier des Vaccinations. Available online: http://inpes.santepubliquefrance.fr/10000/themes/ vaccination/calendrier/calendrier-vaccination.asp (accessed on 7 May 2019). 
35. Blanchard-Rohner, G.; Pollard, A.J. Sustaining immunity after immunization against encapsulated bacteria. Hum. Vaccin. 2008, 4, 309-312. [CrossRef]

36. HCSP. Vaccination des Personnes Immunodéprimées ou Aspléniques. Recommandations Actualisées; Haut Conseil de la Santé Publique: Paris, France, 2014; Available online: https://www.hcsp.fr/explore.cgi/ avisrapportsdomaine?clefr=504 (accessed on 6 February 2018).

37. Bahuaud, M.; Bodilis, H.; Malphettes, M.; Maugard Landre, A.; Matondo, C.; Bouscary, D.; Batteux, F.; Launay, O.; Fermand, J.-P. Immunogenicity and persistence of the 13-valent Pneumococcal Conjugate Vaccine (PCV13) in patients with untreated Smoldering Multiple Myeloma (SMM): A pilot study. Heliyon 2017, 3, e00441. [CrossRef]

Publisher's Note: MDPI stays neutral with regard to jurisdictional claims in published maps and institutional affiliations.

(C) 2020 by the authors. Licensee MDPI, Basel, Switzerland. This article is an open access article distributed under the terms and conditions of the Creative Commons Attribution (CC BY) license (http://creativecommons.org/licenses/by/4.0/). 